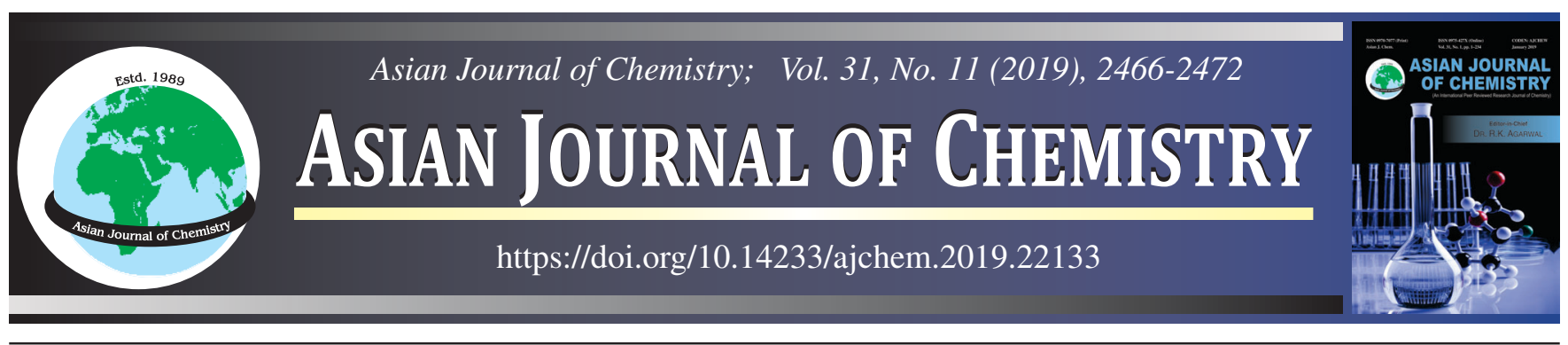

\title{
Distribution of Nutrients in Kelantan River Basin, Malaysia
}

\author{
S. SURATMAN ${ }^{1,2}$ and Y.Y. HeE ${ }^{1, *}$
}

${ }^{1}$ Institute of Oceanography and Environment, Universiti Malaysia Terengganu, 21030 Kuala Nerus, Terengganu, Malaysia ${ }^{2}$ Institute of Tropical Biodiversity and Sustainable Development, Universiti Malaysia Terengganu, 21030 Kuala Nerus, Terengganu, Malaysia

*Corresponding author: E-mail: yueyen_yy@hotmail.com

Received: 13 April 2019;

Accepted: 26 May 2019;

Published online: 28 September 2019;

AJC-19571

This study aims to assess the influences of land use on nutrient concentrations in Kelantan river basin (southern South China Sea), in addition to the effects of monsoon seasons on nutrient concentrations. The dissolved inorganic and organic nutrients in this river were demonstrated to be related to land use during the study period. The middle and lower reaches of the river, which are surrounded by urban areas with high population densities, have enhanced levels of both dissolved inorganic and organic nutrients. Increased rainfall decreased most of the nutrient concentrations in Kelantan river basin, probably due to the dilution effect. According to The Malaysia National Water Quality Standards (NWQS) classification, the mean concentrations of dissolved inorganic phosphorus, nitrite and nitrate in Kelantan river basin fell into Class 1 , which is considered at natural levels in the water column.

Keywords: Nutrients, Anthropogenic activities, Kelantan river basin.

\section{INTRODUCTION}

Malaysia is drained by a dense network of rivers and streams with 54 rivers that discharge to the southern South China sea, carrying with them large quantities of suspended solids $(>$ $75,000 \mathrm{t} \mathrm{y}^{-1}$ ) and nutrients (e.g. ammonia-N > 20,100 t y ${ }^{-1}$ ) [1]. The Kelantan river is the second-largest river in Peninsular Malaysia and located in Kelantan state of Malaysia. The basin has undergone considerable development and rapid land use changes since the 1970's [2]. Human land use within this basin is of growing importance with deforestation (due to logging activities) and agricultural activities increasingly influencing the area, especially in the lower reaches of the river. Kelantan state covers an area of $15,105 \mathrm{~km}^{2}$ with an estimated population of 1,640,400. The downstream section of Kelantan river has a surrounding population of $\sim 0.5$ millions and the population density in the most urbanized area exceeds 20,000 people $/ \mathrm{km}$ [3]. The land cover in Kelantan is dominated by forest reserves $(63.7 \%)$ mainly located in the upstream area of river, followed by agriculture $(30.1 \%)$ [4]. In addition, the built-up area covers about $3.5 \%$ of area and only a small propor-tion is used for transportation, infrastructure and utilities $(1.2 \%)$, while the rest $(1.5 \%)$ is water-bodies. The effect of development pressure, higher population density and increase in agriculture activities potentially lead to increasing anthropogenic impacts on the river.

The state of Kelantan has a typical equatorial climate with constantly warm temperatures and a seasonal distribution of rainfall. Kelantan river basin has an annual precipitation of about $2383 \pm 120 \mathrm{~mm}$, a large amount of which occurs during the wet season that lasts from November to March [5]. The seasonal variation occurring in Malaysia, particularly on the east coast, heavily impacts the river water. In general, high amounts of rainfall will flow into the river water together with nutrients in runoff events during the wet seasons increasing their concentrations in river water [6-8].

Phosphorus and nitrogen are the common nutrients responsible for primary producer (mainly phytoplankton) growth. This primary production is the foundation of aquatic food webs, some of which is then consumed by zooplankton which in turn serves as food for small fish which end up as prey for larger fish. Nutrients therefore play a key role in shaping biomass and productivity in the aquatic environment, as well as fisheries production and the human economy. However, a rich supply of nutrients to the water column can result in eutrophication. Eutrophication is mostly due to nutrient sources related

This is an open access journal, and articles are distributed under the terms of the Attribution 4.0 International (CC BY 4.0) License. This license lets others distribute, remix, tweak, and build upon your work, even commercially, as long as they credit the author for the original creation. You must give appropriate credit, provide a link to the license, and indicate if changes were made. 
to human activities such as runoff from agriculture and development, discharge of domestic sewage and industrial waste with growing human populations, particularly in downstream sections of rivers where pressures are increasing $[9,10]$. Increased nutrients, in turn, can lead to other negative impacts such as reduction in species diversity, decrease in water transparency, damage to coral reefs, development of excessive algal blooms, with the potential for the production of toxins, and other impacts often included under the umbrella term eutrophication $[9,11]$.

Kelantan river, as one of the main rivers in Peninsular Malaysia, is an important water supply to the area. However, ongoing development pressure in the surrounding area may be impacting the river. Monitoring the levels, distribution and sources of nutrients in Kelantan river basin can be helpful in assessing water quality, which has wide implications for the social, economic and human health of the region, as well as being an important issue within the context of the management of Malaysia's rivers. Therefore, spatial and temporal distributions of phosphorus- and nitrogen-based nutrients were determined in this study, where land use and seasonal monsoon effects were taken into account when analyzing the influences on these nutrients in Kelantan river basin. Results obtained for these nutrients were also compared with The Malaysian National Water Quality Standards (NWQS) as listed in Table-1 to determine the suitability of this waterbody for its users [12].

\section{EXPERIMENTAL}

Study site and sampling: The study area focussed on Kelantan river basin (Fig. 1), which is located at east coast of Peninsular Malaysia. Seasonally, the river is subjected to both dry and wet seasons, which are generally associated with varying rainfall. The wet season typically brings heavy rainfall of up to $1750 \mathrm{~mm}$ over the season to this region [2]. River flow ranges from 84 to 1186 (mean 558) $\mathrm{m}^{3} \mathrm{~s}^{-1}$, with higher river flow measurements obtained in the wet season [13-15].

Sampling was performed monthly from August 2011 to November 2011, which covered both the dry and wet seasons. Nine sampling stations were selected from the lower to middle reaches of the main Kelantan River. Stations K8 and K9 are located in the middle reaches of Kelantan river, while stations $\mathrm{K} 1, \mathrm{~K} 2$ and $\mathrm{K} 3$ are downstream stations. The rest of the stations (stations $\mathrm{K} 4, \mathrm{~K} 5, \mathrm{~K} 6$ and $\mathrm{K} 7$ ) are in the middle reaches of the sampling site in this study.

Prior to sampling, all high-density polyethylene bottles (HDPE) were acid-washed and soaked for $24 \mathrm{~h}$ in $10 \% \mathrm{HCl}$, and then rinsed with deionized water and lastly dried before use in order to remove any residues. Surface water samples

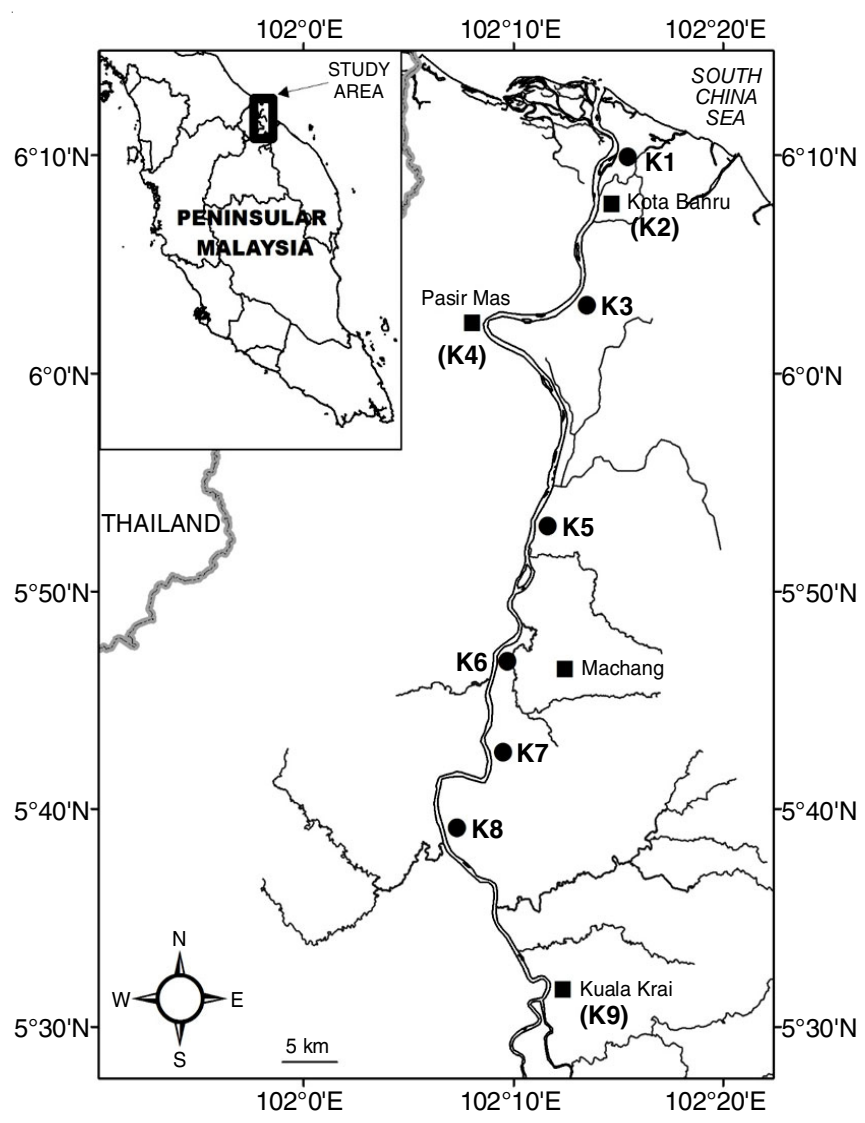

Fig. 1. Sampling stations in Kelantan river basin, Kelantan

were collected under the surface water ( $0.5 \mathrm{~m}$ depth). Samples were immediately stored in an ice box filled with ice and transported to the laboratory. In the laboratory, filtration was undertaken immediately or as soon as practicable to minimize changes in nutrient content due to biological activity, i.e. microbial consumption, cell exudation/lyses and interchanges between particulate and dissolved nutrients. Filtration was carried out with Whatman GF/C filters $(\sim 1.2 \mu \mathrm{m})$ and followed by $0.45 \mu \mathrm{m}$ membrane filters. After that, both filtered and unfiltered samples were then stored at $-20{ }^{\circ} \mathrm{C}$ until analysis.

Chemical analyses: Analyses of dissolved and particulate (both organic and inorganic) phosphorus- and nitrogen-based nutrients were undertaken. The filtrates were analyzed for dissolved inorganic nutrients and urea concentrations using standard colorimetric methods [16]. Dissolved inorganic phosphorus (DIP) was analyzed with the molybdenum blue method. Nitrite $\left(\mathrm{NO}_{2}{ }^{-}\right)$and nitrate $\left(\mathrm{NO}_{3}{ }^{-}\right)$concentrations were measured using the standard pink azo dye method, with $\mathrm{NO}_{3}^{-}$first reduced to $\mathrm{NO}_{2}^{-}$by a cadmium reductor column.

TABLE-1

NATIONAL WATER QUALITY STANDARDS FOR MALAYSIA [Ref. 12]

\begin{tabular}{cccccc}
\hline Parameter & Class I & Class IIA/IIB & Class III & Class IV & Class V \\
\hline $\mathrm{DIP}(\mathrm{mg} / \mathrm{L})$ & Natural & 0.2 & 0.1 & - & Level \\
$\mathrm{NO}_{2}^{-}(\mathrm{mg} / \mathrm{L})$ & level & 0.4 & $0.4(0.03)$ & - & 5 \\
$\mathrm{NO}_{3}^{-}(\mathrm{mg} / \mathrm{L})$ & 0.1 & 7 & 0.9 & 2.7 & above IV \\
$\mathrm{NH}_{4}{ }^{-}(\mathrm{mg} / \mathrm{L})$ & 0.3 & $>2.7$ & $>$ \\
\hline
\end{tabular}

Class I: Conservation of natural environment; Water supply I - Practically no treatment necessary; Fishery I - Very sensitive aquatic species; Class IIA: Water supply II - Conventional treatment required; Fishery II - Sensitive aquatic species; Class IIB: Recreational use with body contact; Class III: Water supply III - Extensive treatment required; Fishery III - Common of economic value and tolerant species; livestock drinking; Class IV: Irrigation; Class V: None of the above. 
Ammonium $\left(\mathrm{NH}_{4}{ }^{+}\right)$and urea concentrations were measured via indophenol and diacetylmonoxime method, respectively. The measurement error based on standard addition of known concentrations was $<5 \%$.

For the determination of dissolved organic phosphorus (DOP) and nitrogen (DON) as well as particulate forms of phosphorus (TPP), an alkaline digestion procedure was used to oxidize all forms of phosphorus and nitrogen to DIP and $\mathrm{NO}_{3}^{-}$[17], which were analyzed as DIP and $\mathrm{NO}_{3}{ }^{-}$. For particulate organic nitrogen (PON) determination, the filter papers with sample retained on top were analyzed by dry oxidation method using a CHNS-O elemental analyzer.

\section{RESULTS AND DISCUSSION}

Rainfall data: The rainfall data obtained from Malaysian Department of Irrigation and Drainage showed that the total monthly values within the study period were in the range 95.0$570.5 \mathrm{~mm}$ (Table-2). The data showed typical Malaysian monsoon seasons with the lowest rainfall occurring in August 2010 (dry season) and the highest in November 2010 (wet season).

Dissolved inorganic nutrients: The mean concentrations of dissolved inorganic nutrients (DIP, $\mathrm{NH}_{4}{ }^{+}, \mathrm{NO}_{2}{ }^{-}$and $\mathrm{NO}_{3}{ }^{-}$) were in the ranges $2.30-5.80 \mu \mathrm{g} / \mathrm{L} \mathrm{P}, 150-318 \mu \mathrm{g} / \mathrm{L} \mathrm{N}, 0.88$ $2.06 \mu \mathrm{g} / \mathrm{L} \mathrm{N}$ and 204-279 $\mu \mathrm{g} / \mathrm{L} \mathrm{N}$, respectively, across the nine stations with four sampling times. Fig. 2 shows the histograms
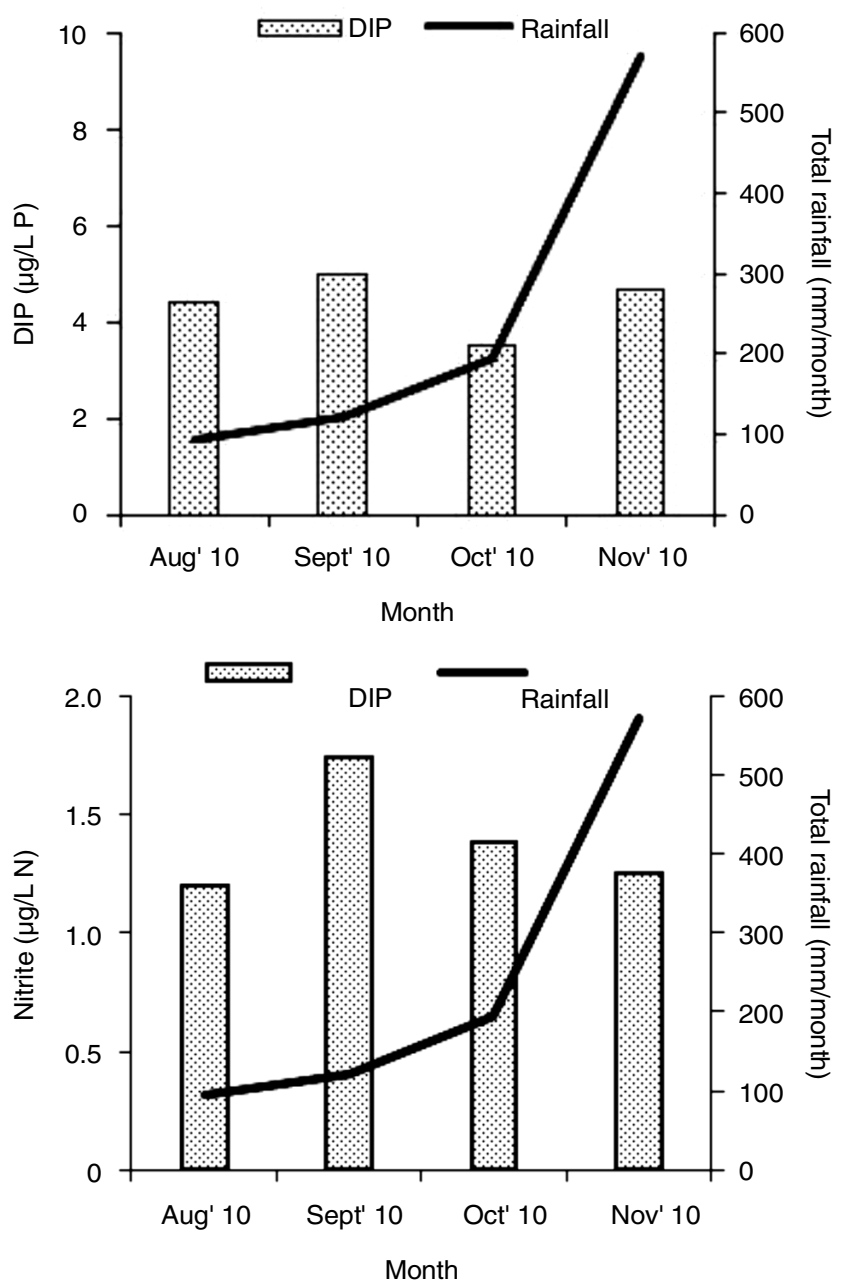

TABLE-2

MONTHLY RAINFALL DATA AT THE SITE OF CHABANG

TIGA PENDEK, KELANTAN LOCATED NEAR THE STUDY AREA DURING THE STUDY PERIOD

\begin{tabular}{cc}
\hline Month & Total monthly rainfall $(\mathrm{mm} / \mathrm{month})$ \\
\hline Aug-2010 & 95.0 \\
Sep-2010 & 122.5 \\
Oct-2010 & 195.0 \\
Nov-2010 & 570.5 \\
\hline
\end{tabular}

based on the results of monthly mean concentrations of these nutrients from the nine sampling stations. Over the four sampling times, these nutrients generally showed the highest mean DIP, $\mathrm{NO}_{2}{ }^{-}$and $\mathrm{NO}_{3}{ }^{-}$values in September, with the exception of $\mathrm{NH}_{4}{ }^{+}$. Although the highest mean $\mathrm{NH}_{4}{ }^{+}$did not occur in the month of September, the mean concentration in this month was the second highest after the November sampling. Spatially, mean concentrations of DIP were generally higher in the middle reaches of Kelantan river (Fig. 3) as well as at station K2. For dissolved inorganic nitrogen, higher mean concentrations were recorded from the downstream stations than those from the middle reach of the river, although a sudden peak of $\mathrm{NO}_{2}{ }^{-}$ happened at the middle reach station (station K9).

Dissolved organic nutrients: Overall, the mean concentrations of DOP, DON and urea were in the range 9.83-16.73 $\mu \mathrm{g} / \mathrm{L} \mathrm{P}, 186-363 \mu \mathrm{g} / \mathrm{L} \mathrm{N}$ and 1.80-8.63 $\mu \mathrm{g} / \mathrm{L} \mathrm{N}$, respectively.
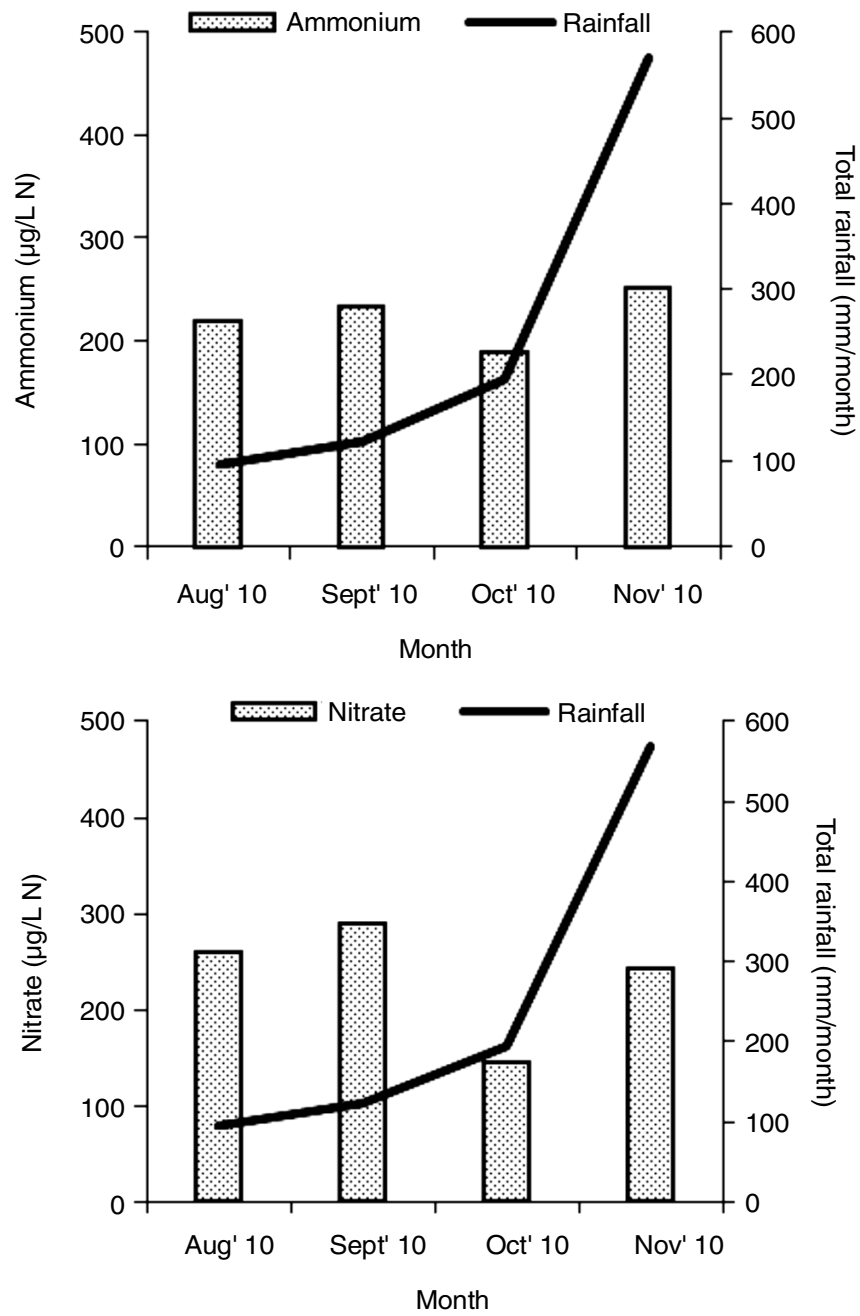

Fig. 2. Monthly variation of mean nutrient concentrations with respective to total monthly rainfall 

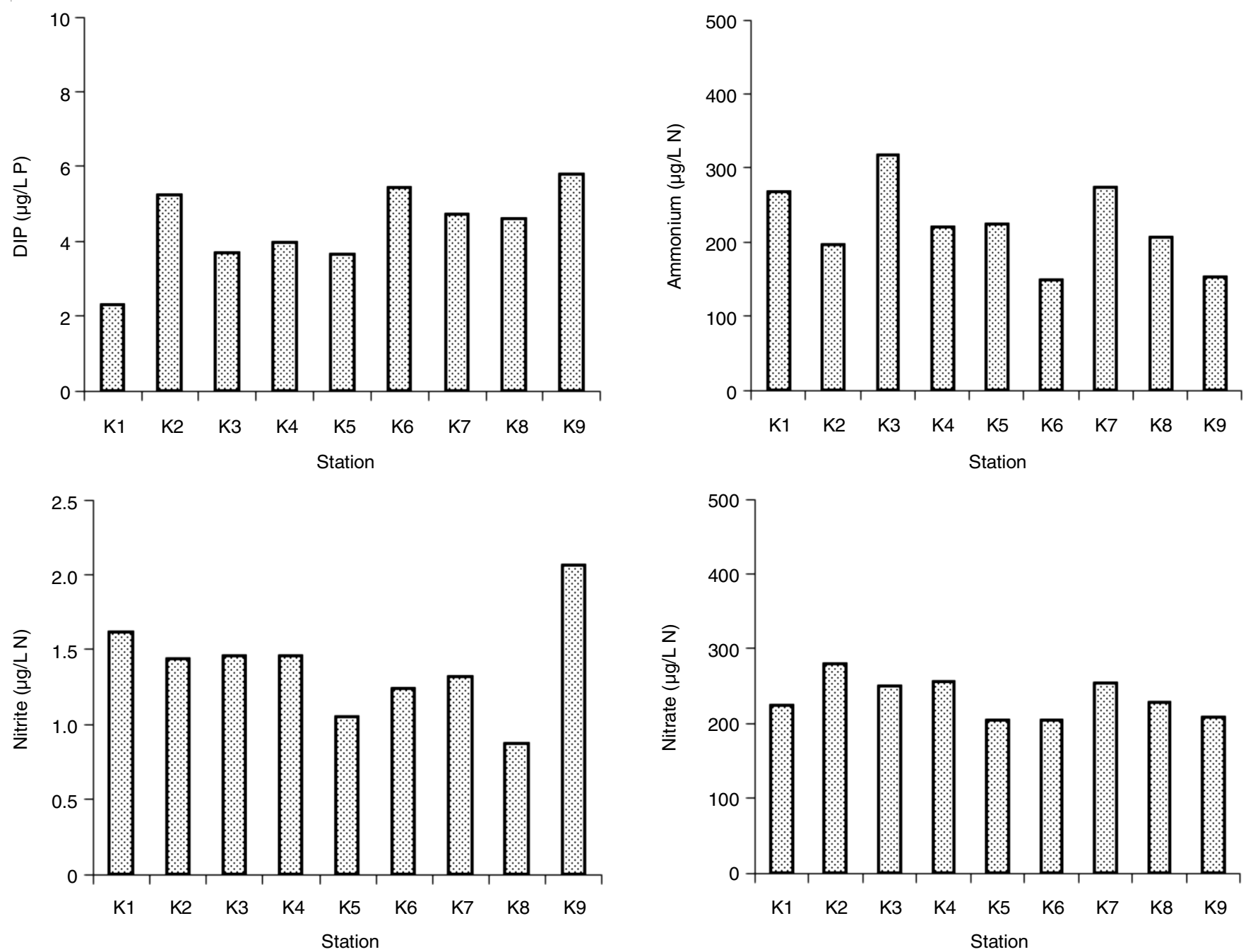

Fig. 3. Spatial variation of mean nutrient concentrations in the Kelantan River basin
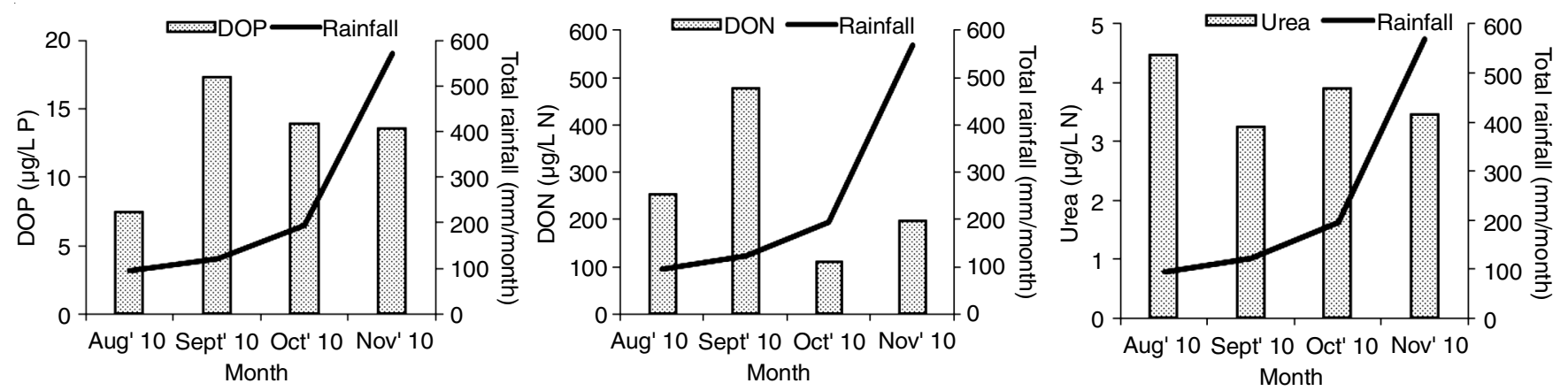

Fig. 4. Monthly variation of mean dissolved organic nutrient concentrations with respective to total monthly rainfall

Fig. 4 shows the histograms for the monthly mean dissolved organic nutrient concentrations present in the surface waters of nine stations. In general, the surface distributions of DOP and DON broadly followed their dissolved inorganic forms (i.e. DIP, $\mathrm{NO}_{2}{ }^{-}$and $\mathrm{NO}_{3}{ }^{-}$), showing higher mean concentrations in September month. For urea, the highest mean concentration remained in the dry season but occurred in August month instead of September month. In terms of spatial distribution (Fig. 5), DOP and DON showed a similar trend in that higher mean concentrations were found in the middle reaches of the river, with some other higher DON mean concentrations observed at the furthermost downstream stations. Meanwhile, higher urea mean concentrations were observed at the downstream station.

Particulate nutrients: For TPP and PON, the mean concentrations of these nutrients ranged between 23.8 and $54.2 \mu \mathrm{g} / \mathrm{L}$ $\mathrm{P}$ and 159 and $328 \mu \mathrm{g} / \mathrm{L} \mathrm{N}$, respectively. The histograms for monthly particulate nutrients (TPP and PON) mean concentrations present in the surface water from nine stations are shown in Fig. 6. These clearly show that PON mean concentrations were higher in the dry season (i.e. August and September) than in the wet season (i.e. October and November). For TPP, there 

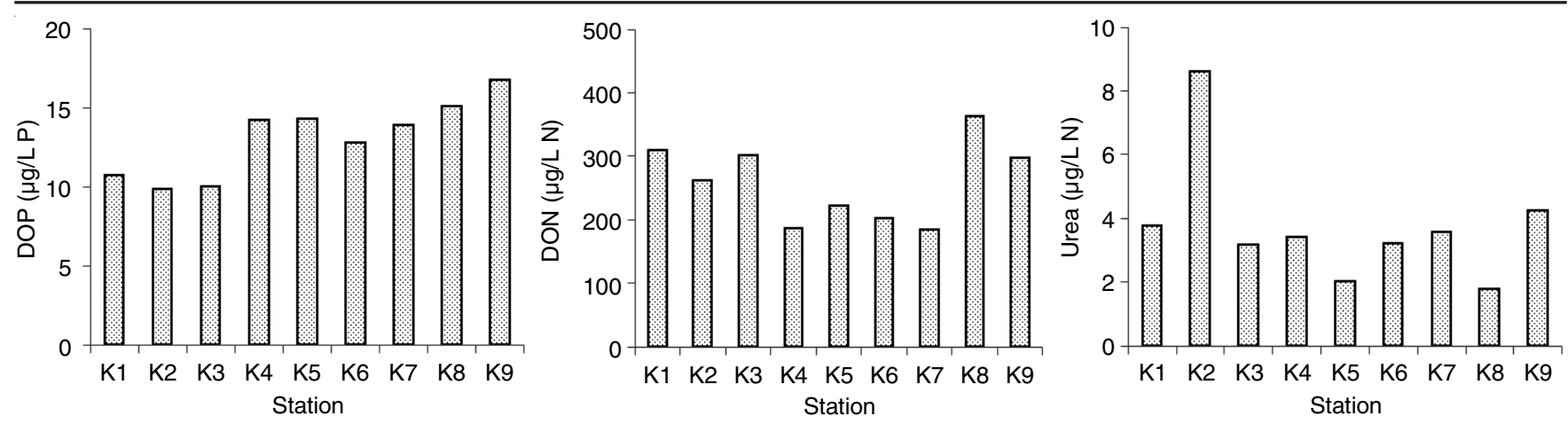

Fig. 5. Spatial variation of mean dissolved organic nutrient concentrations in Kelantan river basin
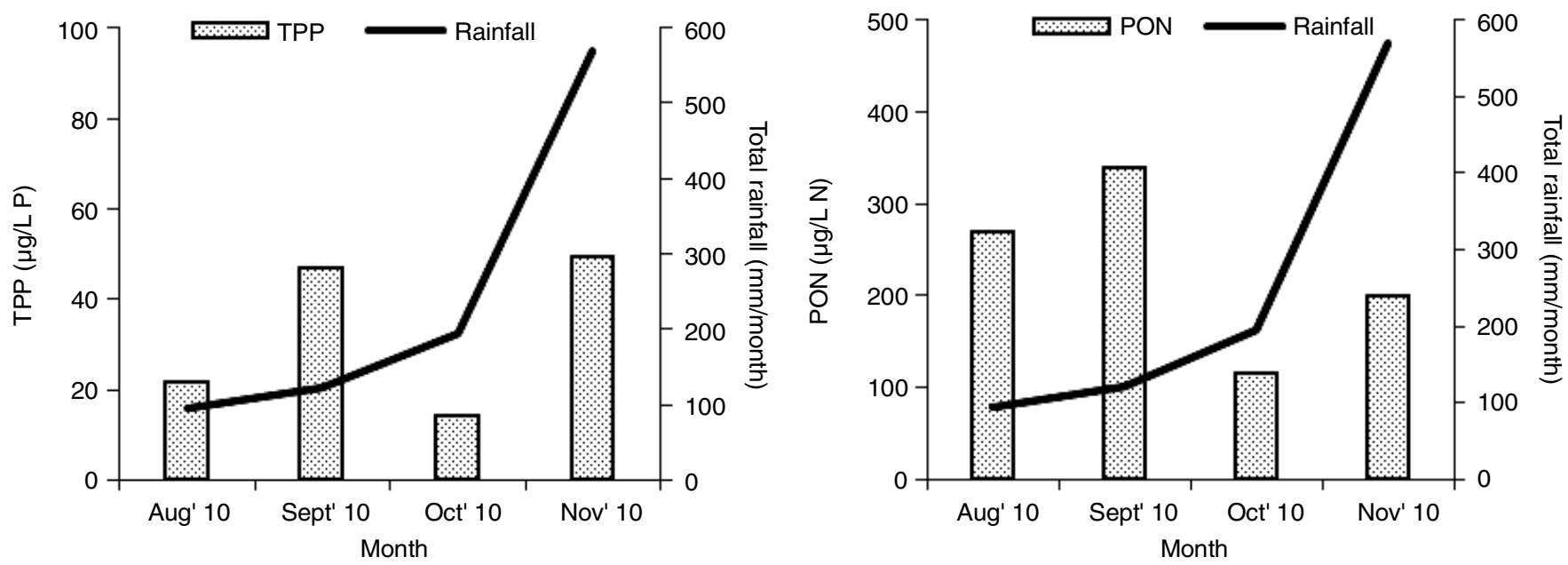

Fig. 6. Monthly variation of mean particulate $\mathrm{P}$ and $\mathrm{N}$ concentrations with respective total monthly rainfall

was no discernible trend between the dry and wet seasons, with higher mean concentrations found in September and November months. Spatially, TPP shows higher mean concentrations in the middle reaches of river compared to downstream, although a sudden peak was seen at the furthest-downstream station (station K2) (Fig. 7). The highest mean PON concentration occurred at station $\mathrm{K} 7$, but overall there was no general spatial trend across the river.

Spatial distribution of nutrients: Studies of Malaysia's rivers have reported that anthropogenic activities have contri- buted to increase in nutrient concentrations in these rivers, especially in middle to downstream areas [7,18,19]. In this study, the results revealed that higher mean concentrations of dissolved inorganic nutrients occurred at the middle reaches of the river and downstream stations, reflecting that two sources contributed to higher concentrations of these nutrients in Kelantan river basin. The highest mean DIP concentrations were found at the middle reach station (station $\mathrm{K} 9$ ) which is close to the town of Kuala Krai, while DIN $\left(\mathrm{NH}_{4}{ }^{+}, \mathrm{NO}_{2}{ }^{-}\right.$and $\left.\mathrm{NO}_{3}{ }^{-}\right)$in this study was generally higher downstream near Kelantan's capital

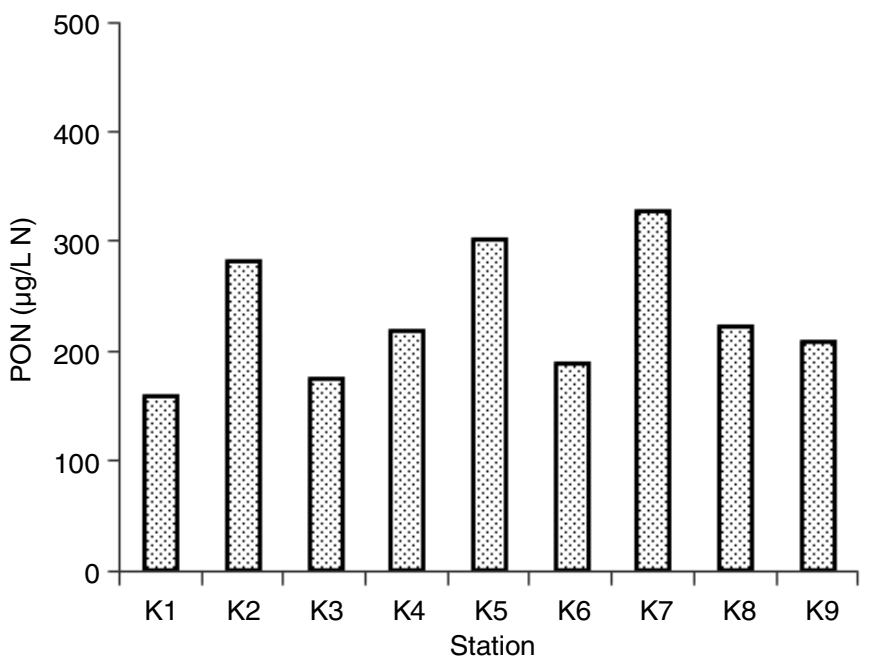

Fig. 7. Spatial variation of mean concentration of particulate $\mathrm{P}$ and $\mathrm{N}$ in Kelantan River basin 
city (Kota Bharu), reflecting the impact from these urban areas. The point source contribution from sewage effluent input is a major source of $\mathrm{P}$ and $\mathrm{N}$ and increases the $\mathrm{P}$ and $\mathrm{N}$ concentrations in the rivers [20,21]. Phosphorus present in washing powders, detergent and human waste can contribute $\mathrm{P}$ in sewage and end-up increasing the flux of $\mathrm{P}$ to the river [22-24]. Suratman et al. [8] found in their study that higher DIN in the town area was probably due to residential sewage from the housing areas. Therefore, improper domestic waste disposal from the concentrated housing areas could be accelerating the accumulation of DIP and DIN in the water column and raising the concentrations of these compounds in Kelantan river, especially in urbanized downstream areas with high population densities.

The general pattern of dissolved organic forms is similar but not identical to their dissolved inorganic forms, indicating that there are anthropogenic sources of DOP and DON as their dissolved inorganic forms. Pellerin et al. [25] found in their study that urban watersheds in general have higher dissolved organic nutrients than undisturbed forested watersheds, where sources of dissolved organic nutrients such as wastewater may be important in disturbed watersheds. As mentioned, Kuala Krai and Kota Bharu are the important towns in Kelantan with increasing settlement areas observed in Kota Bharu. The enrichment of dissolved organic nutrients in the town areas is therefore not surprising and could be attributed to the delivery of wastewater from those housing areas as a point source [25].

On the other hand, the higher dissolved organic nutrients concentrations occurred at the stations where dissolved inorganic nutrients concentrations were likely to be derived from in situ primary production due to the biological process of increase in inorganic nutrient uptake by phytoplankton as a result of increased dissolved inorganic nutrient concentrations. Previous studies of the rivers on the east coast of Peninsular Malaysia have found that particulate nutrients were largely associated with suspended particulate matter $[7,8]$. However, the unclear trend of TPP and PON in this study and decoupling of TPP and PON with total suspended solid (TSS) (Fig. 8) has not been able to confirm the contributors to these nutrients in Kelantan River. Therefore, more sampling and analysis are needed in order to identify the sources of particulate nutrients in this river.
Effect of wet and dry seasons on nutrient distributions: Phosphorus- and nitrogen-based nutrients in this study exhibited seasonal variations; the nutrients in Kelantan river were higher in the dry season (i.e. September). Unlike some of the rivers on the east coast of peninsular Malaysia, which had higher nutrient concentrations in the water column during the wet season and lower nutrient concentrations in the dry season [6-8], the nutrient concentrations in Kelantan river basin were generally higher during the dry season and had an inverse relationship with rainfall. In previous studies, in rivers of east coast of Peninsular Malaysia, Hee et al. [7] and Suratman et al. [8] found that higher P- and N-based nutrient concentrations in Setiu river occurred in the wet season, probably due to $\mathrm{P}$ and $\mathrm{N}$ loss from the surrounding areas through soil leaching and land runoff from agricultural land with over-fertilization during the heavy rainfall season. In the current study, by contrast, dilution of nutrient concentrations by higher rainfall in the wet season was probably the main driver for $\mathrm{P}$ and $\mathrm{N}$ compounds declining from the dry to wet seasons [26]. This result is somewhat similar with Ling et al. [27] in Batang Baram, Sarawak province, who reported some of the nutrient concentrations in their study were higher when there was no rain. They explained that the higher concentrations of these nutrients originated from the longhouses and logging activities and these nutrients were diluted by rain, leading to lower nutrient concentrations in the river during the rainfall event.

Comparison with Malaysian National Water Quality Standards: The main source of drinking water in Malaysia comes from rivers. In addition to serving as drinking water, rivers in Malaysia provide water for agriculture, industry, recreational use, etc. In Malaysia, minimum river water quality standards are established by the Department of Environment and these standards are intended to serve as a basis for the environmental assessment of a river in relation to pollution load categorization and to protect designated uses of rivers under the NWQS [28-30]. Based on the water analysis in this study, Kelantan river did not have any data or results that indicate it exceeded the Malaysian guidelines for water quality during the study period, except $\mathrm{NH}_{4}{ }^{+}$that fell in the Class IIA/IIB. Among DIP, $\mathrm{NO}_{2}{ }^{-}$and $\mathrm{NO}_{3}{ }^{-}$, overall mean concentrations of
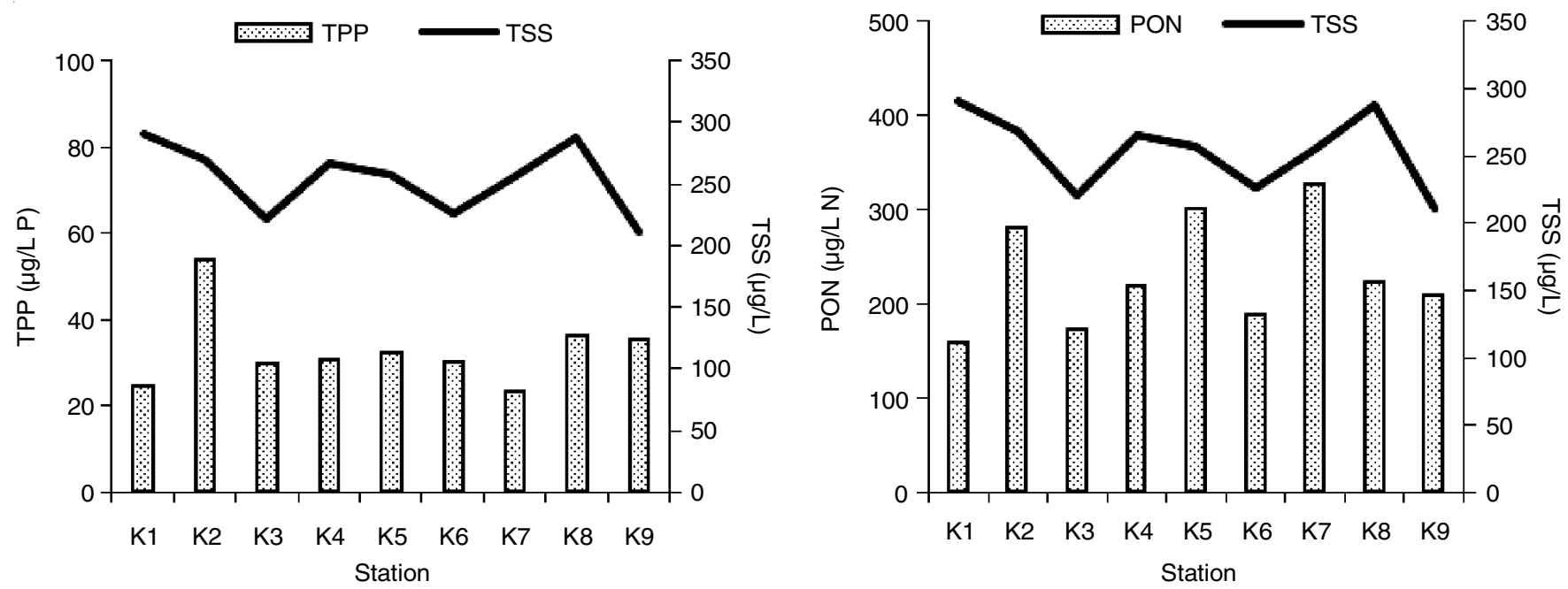

Fig. 8. Variation of mean particulate $\mathrm{P}$ and $\mathrm{N}$ concentrations with respective to TSS 
$\mathrm{NO}_{2}{ }^{-}(1.39 \mu \mathrm{g} / \mathrm{L} \mathrm{N})$ were farthest from falling out of Class IIA/ IIB (Table-1) with about 300 time lower than the threshold value of $400 \mu \mathrm{g} / \mathrm{L} \mathrm{N}$. Although the concentrations of DIP, $\mathrm{NO}_{2}{ }^{-}$ and $\mathrm{NO}_{3}{ }^{-}$across the river varied spatially. The mean concentrations of these nutrients in Kelantan river over the four sampling times fall into Class 1 . Under this category, water supplied from this river requires practically no treatment and is suitable for conservation aquatic species. In NWQS, dissolved organic and particulate matter are not listed in this classification, therefore no comparison can be made.

\section{Conclusion}

The results have shown that relatively higher concentrations of dissolved inorganic and organic nutrients in Kelantan river were found in urban areas i.e. Kuala Krai and Kota Bharu town with high population densities. The point source contribution from sewage effluent input has been suggested as the major source of $\mathrm{P}$ and $\mathrm{N}$ to the river increasing the $\mathrm{P}$ and $\mathrm{N}$ concentrations in the water column. Seasonally, the concentrations of nutrients were generally influenced by the rainfall amount, with higher concentrations of nutrients mostly recorded in the dry season. Although the concentrations of DIP, $\mathrm{NO}_{2}{ }^{-}$ and $\mathrm{NO}_{3}{ }^{-}$across the river varied spatially, in comparison with the National Water Quality Standards (NWQS) classification for Malaysia, the mean concentrations of these nutrients in Kelantan river basin over the four sampling times fall into the Class 1 . Under this category, practically no treatment is necessary for use as water supply and it is suitable for conservation of aquatic species.

\section{ACKNOWLEDGEMENTS}

This study was partially supported by Ministry of Education, Malaysia (Fundamental Research Grant Vote No. 59313) and Higher Institution Centre of Excellence (HICoE) Research Grant (Vote No. 66928). The assistance of Suhairah Abas and Wong Kail Ling in the sampling and analysis is kindly acknowledged. Thanks to Dr. Rose Norman for assistance with proof reading of the manuscript.

\section{CONFLICT OF INTEREST}

The authors declare that there is no conflict of interests regarding the publication of this article.

\section{REFERENCES}

1. L. Talaue-McManus, Transboundary Diagnostic Analysis for the South China Sea; EAS/RCU Technical Report Series No. 14. Bangkok: UNEP. pp 105 (2000).

2. N.A. Adnan and P.M. Atkinson, Int. J. Climatol., 31, 815 (2011); https://doi.org/10.1002/joc.2112.

3. DOS (Department of Statistic), In: Statistic handbook Malaysia 2011. Department of Statistic, Malaysia, pp 79 (2012).

4. BMGN (The Land Use Information Division), The Landuse Report 2012; Kuala Lumpur: GMGN. 48pp. (2012).
5. J.H. Abdulkareem and W.N.A., Sulaiman, J. Teknol., 78, 115 (2016).

6. S. Suratman, N.M. Tahir, L.C. Yeow and S.R.A. Rashid, Malays. J. Anal. Sci., 10, 143 (2006).

7. Y.Y. Hee, S. Suratman, N.M. Tahir and T. Jickells, Sains Malays., 47, 883 (2018); https://doi.org/10.17576/jsm-2018-4705-03.

8. S. Suratman, Y.Y. Hee and N.M. Tahir, J. Eng. Appl. Sci., 13, 8838 (2018),

9. M. Selman, S. Greenhalgh, R. Diaz and Z. Sugg, Eutroph. Hypoxia, 1, 1 (2008).

10. H.J. Qu and C. Kroeze, Sci. Total Environ., 408, 2075 (2010); https://doi.org/10.1016/j.scitotenv.2009.12.015.

11. B. Grizzetti, F. Bouraoui, G. Billen, H. van Grinsven, A.C. Cardoso, V. Thieu, J. Garnier, C. Curtis, R. Howarth and P. Johnes, The European Nitrogen Assessment, Cambridge University Press: U.K., pp 612 (2011).

12. DOE, Malaysia Environmental Quality Report 2010. Department of Environment, Ministry of Natural Resources and Environment Malaysia. pp. 78 (2011).

13. DID (Department of Irrigation and Drainage), In: Water Resources Publication No. 21. Malaysia, pp 88 (2009).

14. A.R. MatAmin, F. Ahmad, M. Mamat, M. Rivaie and K. Abdullah, Ecol. Quest., 16, 99 (2012); https://doi.org/10.12775/v10090-012-0010-6.

15. T.P.R.S. Hussain and H. Ismail, World Appl. Sci. J., 28, 1989 (2013).

16. K. Grasshoff, M. Ehrhardt and K. Kremling, Determination of Nutrients, In: Methods of Seawater Analysis, Verlag Chemie: Florida, edn 2, pp 419 (1983).

17. H.P. Hansen and F. Koroleff, Methods of Seawater Analysis, WileyVCH: New York, pp 600 (1999).

18. S. Suratman, Y.Y. Hee and N.M. Tahir, Asian J. Chem., 26, 2047 (2014); https://doi.org/10.14233/ajchem.2014.15644.

19. M.I. Mohd Sailan, Y.Y. Hee, E.A. Bedurus and M.T. Latif, Sains Malays., 44, 67 (2015); https://doi.org/10.17576/jsm-2015-4401-10.

20. D.O. Hessen, Adv. Ecol. Res, 29, 1 (1999); https://doi.org/10.1016/S0065-2504(08)60190-7.

21. Z. Shen, Q. Lin, S. Zhang, H. Miao and P. Zhang, Ambio, 32, 334 (2003)

22. L.S. Hoo, A. Samat and M.R. Othman, Malays. J. Anal. Sci., 7, 157 (2001).

23. J. Némery, J. Garnier and C. Morel, Biogeochemistry, 72, 35 (2005); https://doi.org/10.1007/s10533-004-0078-1.

24. C. Liu, C. Kroeze, A.Y. Hoekstra and W. Gerbens-Leenes, Ecol. Indic., 18, 42 (2012); https://doi.org/10.1016/j.ecolind.2011.10.005.

25. B.A. Pellerin, S.S. Kaushal and W.H. McDowell, Ecosystems (N. Y.), 9, 852 (2006); https://doi.org/10.1007/s10021-006-0076-3.

26. S. Rostami, J. He and Q.K. Hassan, Environ., 5, 1 (2018); https://doi.org/10.3934/environsci.2018.1.1.

27. T.-Y. Ling, C.-L. Soo, J.-J. Liew, L. Nyanti, S.-F. Sim and J. Grinang, Pol. J. Environ. Stud., 26, 2053 (2017); https://doi.org/10.15244/pjoes/69439.

28. E.Z. Zainudin, Benchmarking River water Quality in Malaysia (2010); http://irep.iium.edu.my/2954/1/Feature-BenchmarkingRiverWater 3pp.pdf. Accessed in February 2019.

29. Y.F. Huang, S.Y. Ang, K.M. Lee and T.S. Lee, Quality of Water Resources in Malaysia (2015); https://www.intechopen.com/books/research-and-practices-in-waterquality/quality-of-water-resources-in-malaysia. Accessed in February 2019.

30. I. Naubi, N.H.M. Zardari, S.M. Shirazi, N.F.B. Ibrahim and L. Baloo, Pol. J. Environ. Stud., 25, 231 (2016); https://doi.org/10.15244/pjoes/60109. 